\title{
BASIC PLASMA FEATURES OF PLANAR JET FORMED BY CAPACITIVE RF DISCHARGE IN ATMOSPHERE PRESSURE ARGON
}

\author{
V.Yu. Bazhenov, S.M. Gubarev, V.V. Tsiolko \\ Institute of Physics NAS of Ukraine, Kyiv, Ukraine \\ E-mail: gubarev@iop.kiev.ua
}

\begin{abstract}
Upgraded method of determining basic parameters of weakly ionized plasma by means of photometric study of bremsstrahlung emission continuum in visible spectrum range is described. Time-averaged spatial distributions of electron temperature and density in planar plasma jet formed by capacitive RF discharge in atmosphere pressure argon at the discharge glow in a low-current $\alpha$-mode are experimentally obtained.
\end{abstract}

PACS: 52.80.Pi; 52.70.- $\mathrm{m}$

\section{INTRODUCTION}

Recently, plasma jets at atmosphere pressure attract significant attention for various technological applications and basic studies of the plasma parameters. This interest is due to the application prospects of such plasma jets for polymer surface treatment [1], etching different materials [2, 3], substrate cleaning, biomedical applications [4], etc. The last is of especial interest due to relatively low gas temperature of the plasma jet at atmosphere pressure which is drastically less than mean electron kinetic energy.

Electron temperature and density are basic features which determine plasma properties and kinetics, as well as concentration of active species in the plasma. Optical emission spectroscopy (OES) is one of the most widely used techniques of non-perturbing studies of the atmosphere pressure plasma jets. Electron concentration in low temperature plasma is determined by different OES methods: Stark broadening of $\mathrm{H}_{\beta}$ line from hydrogen Balmer series [5], emission line-ratio method associated with electron density in a frame of collisional-radiative model (CRM) [6] and by analysis of the plasma emission continuum. Electron temperature is often determined by ratio of relative intensities of atomic emission lines assuming that excitation temperature is close to that of the plasma electrons. Particularly, in [7] CRM is proposed for determining effective electron temperature by experimentally measured relative intensities of four argon emission lines. The model assumes maxwellian EEDF and is based on equations of population balance of any four excited levels from ten $4 p$ ones (in Paschen's notation) of argon. Usability of this model is limited by optically thin plasma for which electron excitation kinetics dominates over atom-induced excitation one, for instance, in plasma of atmosphere pressure micro-discharges. The method requires knowledge of electron hit excitation cross sections from ground and metastable levels to $2 \mathrm{p}$ argon levels, and is somewhat complex and slow.

In [8] photometric method of determining spatial distribution of electron temperature $T_{e}$ in weakly ionized plasma of atmosphere pressure jet by means of neutral bremsstrahlung emission measurements. At that, image of the plasma jet cross section were obtained by means of digital single lens reflex (DSLR) photo camera with spectrum selection provided by sequential use of two narrow-band filters (1.5 nm FWHM) with transmission maxima at 514.5 and $632.8 \mathrm{~nm}$, and $\mathrm{T}_{\mathrm{e}}$ spatial dis- tribution was obtained from ratio of emission intensities at two mentioned wavelengths for each point of the discharge image.

Unlike the procedure described in [8] we used selection of the bremsstrahlung emission spectrum ranges by inherent color separation of the DSLR photo camera in broad blue and green spectrum without the use of any additional filters.

The present paper is a continuation of our previous researches of atmosphere pressure $\mathrm{RF}$ discharge and features of formed by it planar plasma jet $[1,9,10]$, and is devoted to application of upgraded photometric method [10] for determining electron temperature spatial distributions aimed at planar plasma jet diagnostics.

\section{EXPERIMENTAL SETUP AND METHODS}

Scheme of the experimental setup (Fig. 1) is similar to one used in our earlier work [1]. Capacitive RF (13.56 MHz) discharge glowed in a $1 \mathrm{~mm}$ thick gas filled space between two planar parallel electrodes 1 with dielectric barriers 2 made of alumina ceramics each having $50 \times 10 \mathrm{~mm}$ dimensions and $1 \mathrm{~mm}$ thickness. The main discharge cell (I) was placed vertically, and plasma jet (II) came out of it towards additional grounded electrode 3 . Isolated movable plate 4 could be used as substrate holder. Commercial RF generator with $250 \mathrm{~W}$ maximum output power 5 and custom module of impedance matching 6 were used for power supply to the discharge electrodes by means of capacitive dividers $\mathrm{C} 1-\mathrm{C} 2$ and $\mathrm{C} 3-\mathrm{C} 4$. Volumetric argon supply rate was controlled by working gas feed system 7 and comprised 6.5 liters per minute. The main discharge current range used in our studies was $50 \ldots 60 \mathrm{~mA} / \mathrm{cm}^{2}$ which corresponded to $\alpha$-mode of the discharge glow. More detailed description of the setup and the procedure of adjustment $\mathrm{U}_{\mathrm{H}}$ (high potential) and $\mathrm{U}_{\mathrm{L}}$ (low potential) values for optimum formation of the plasma jet can be found in [1].

For non-perturbing studies of the plasma jet formed by RF discharge 8-Mpixel DSLR photo camera CanonEOS-350D was used at low sensitivity setting of 100 international standardization organization (ISO) units for reducing camera sensor noise. Experimentally optimized optical arrangement provided the imaging with side view of the plasma jet by means of a lens having $30 \mathrm{~mm}$ focal length (Fig. 2). Exposure time of 1/125 s provided time-averaged detection of the plasma emission. For fulfilling the depth-of-field requirement, the lens was stopped down to 1:8 relative aperture, and the 
plasma jet width was reduced to $2 \mathrm{~cm}$ by placement of additional glass plate having $1 \mathrm{~mm}$ thickness onto the grounded electrode (Fig. 2). Experimentally determined optical resolution was about $150 \mu \mathrm{m}$ in the jet region.

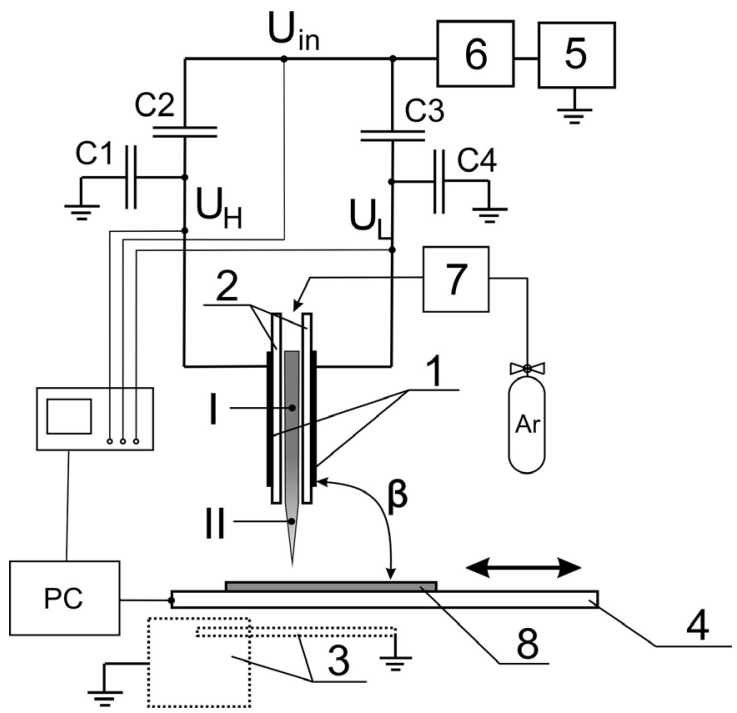

Fig. 1. Experimental setup: 1 - two powered RF electrodes; 2 -dielectric barriers; 3 -third grounded electrode; 4 -working table; 5 - RF generator; 6 - matching unit; 7 - argon flow regulation unit;

8 - substrate; $I-R F$ discharge main plasma; II - RF plasma jet

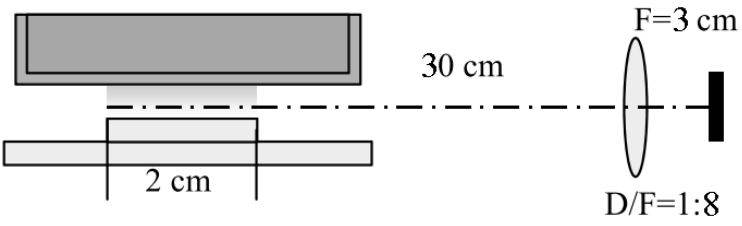

Fig. 2. Scheme of the plasma jet emission intensity profile imaging

Spatial profiles of the jet emission intensity were determined using RAW files from the camera processed by UFRaw and ImageJ freeware with linear conversion function. At that, only the data of blue and green image channels were analyzed since red channel data were affected by essential presence of argon emission lines. For ensuring precise photometric spectrum-integrated measurements, special calibration procedure was performed described in details in [10]. Resulted curves of spectrum sensitivity for mentioned color channels are shown in Fig. 3.

Earlier developed by us procedure [10] for determining $T_{e}$ spatial distribution inside the discharge cell was applied for non-perturbing study of the plasma jet. Following from an assumption of maxwellian EEDF shape one can use an expression for spectrum distribution of bremsstrahlung (electron - neutral atom) continuum intensity

$$
\epsilon_{e a} \propto \frac{n_{e} n_{a}}{\lambda^{2}} \frac{1}{\left(k T_{e}\right)^{3 / 2}} \int_{h c / \lambda}^{\infty} Q_{e a}(\lambda, E) E e^{-E / k T_{e}} d E,
$$

which is dominating source of light emission from studied discharge in blue and green spectrum ranges. Here $\mathrm{n}_{\mathrm{e}}$ is the electron concentration; $\mathrm{n}_{\mathrm{a}}$ is the concentration of working gas atoms; $\lambda$ is the emission wavelength; $\mathrm{k}-$ is the Boltzmann constant; $\mathrm{T}_{\mathrm{e}}$ is the electron temperature; $\mathrm{Q}_{\mathrm{ea}}$ is the neutral bremsstrahlung cross section; $\mathrm{E}$ is the electron energy.

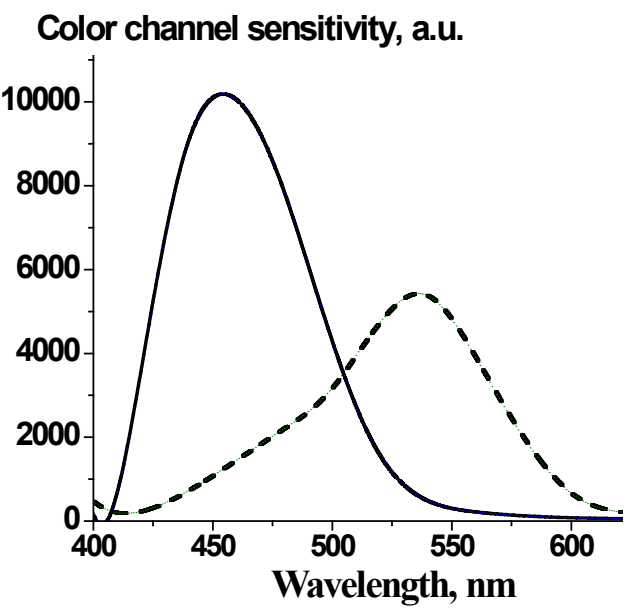

Fig. 3. Color channel spectral sensitivity of DSLR camera Canon-EOS-350D. Solid line - for blue channel, dash line - for green channel

The ratios of blue to green values of convolution between the bremsstrahlung plasma emission spectrum calculated using (1) and wavelength dependence of the camera sensor sensitivity for respective color channel on wavelength $q(\lambda)$ were calculated for different $T_{e}$. It should be noted that the calculated ratio $\left(\varepsilon_{\text {ea }}(\lambda) \cdot q_{\text {blue }}(\lambda)\right) /\left(\varepsilon_{\text {ea }}(\lambda) \cdot q_{\text {green }}(\lambda)\right)$ is a function of the electron temperature $T_{e}$ and does not depend on the electron concentration. Calculated in such a way dependence for particular Canon EOS-350D digital camera used in our experiments is presented in Fig. 4. One can easily see from the dependence shape that it can be used for unambiguous solving the inverse problem that is, determining $\mathrm{T}_{\mathrm{e}}$ spatial distribution by measured blueto-green readout ratios from the discharge image.

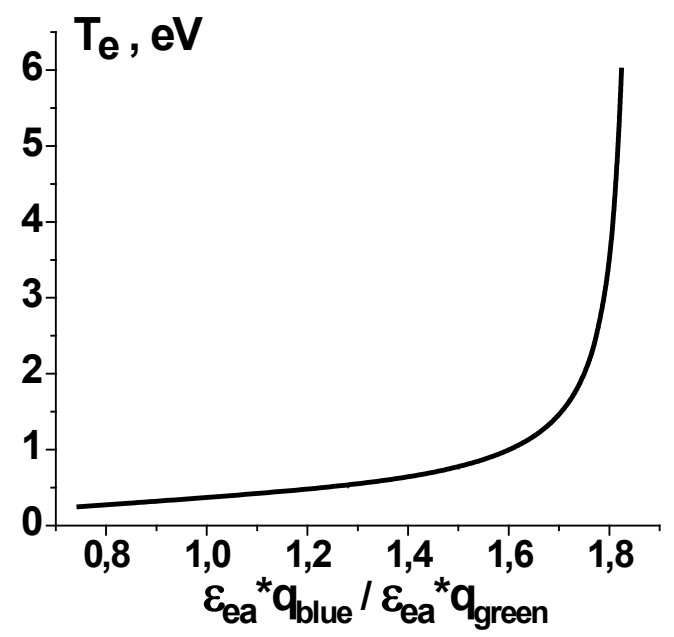

Fig. 4. Calculated relation between $R F$ discharge plasma electron temperature $T_{e}$ and blue-to-green readout ratio of Canon EOS $350 D$ camera sensor 


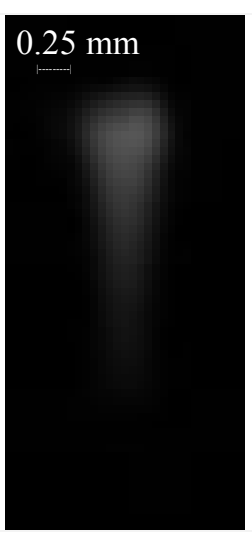

$-3$
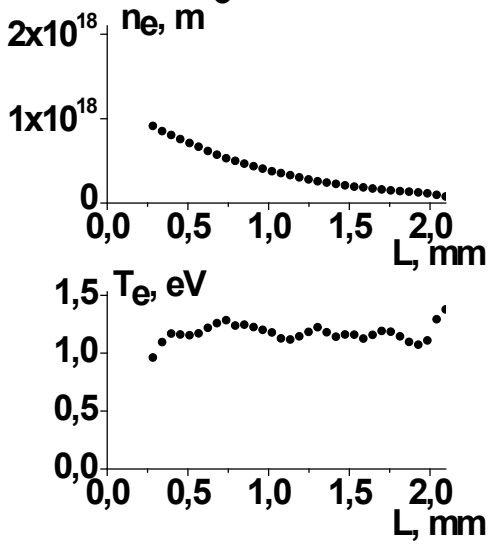

$\mathrm{U}_{\mathrm{H}}=350 \mathrm{~V}, \mathrm{U}_{\mathrm{L}}=35 \mathrm{~V}$, $\mathrm{J}_{\mathrm{d}}=50 \mathrm{~mA} / \mathrm{cm}^{2}$

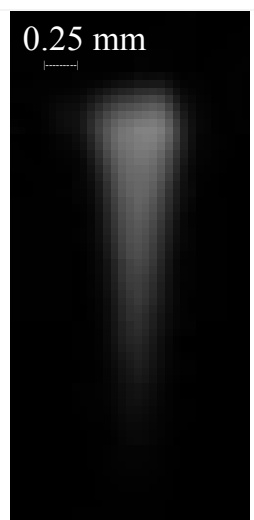

$-3$
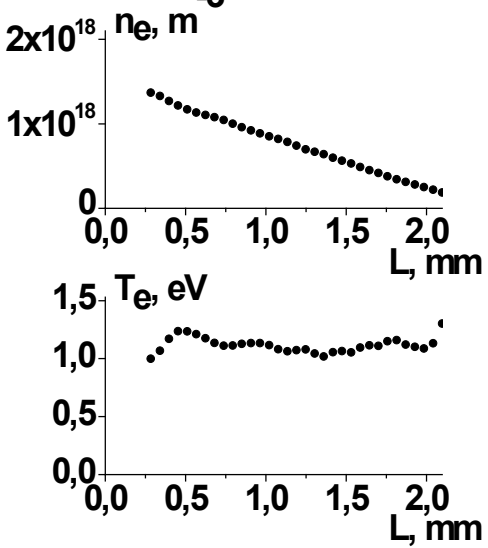

$$
\begin{gathered}
\mathrm{U}_{\mathrm{H}}=400 \mathrm{~V}, \mathrm{U}_{\mathrm{L}}=65 \mathrm{~V}, \\
\mathrm{~J}_{\mathrm{d}}=55 \mathrm{~mA} / \mathrm{cm}^{2}
\end{gathered}
$$

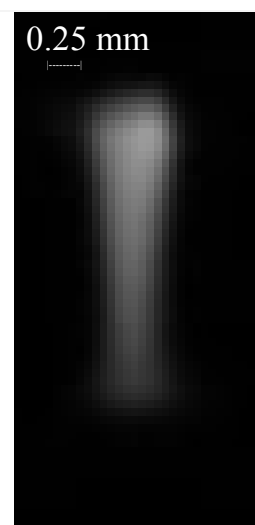

$-3$
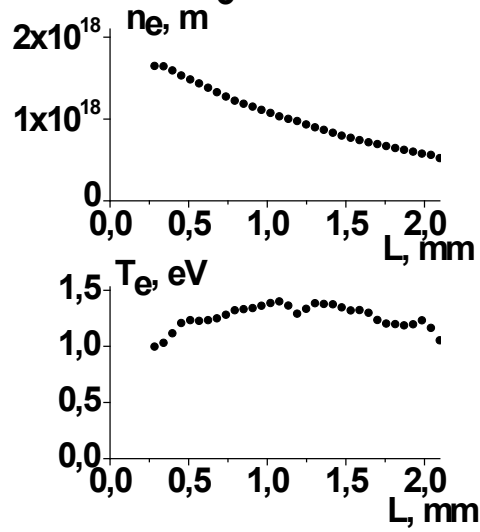

$\mathrm{U}_{\mathrm{H}}=435 \mathrm{~V}, \mathrm{U}_{\mathrm{L}}=74 \mathrm{~V}$,
$\mathrm{J}_{\mathrm{d}}=60 \mathrm{~mA} / \mathrm{cm}^{2}$

Fig. 5. Images of planar plasma jet and respective determined $T_{e}$ and $n_{e}$ spatial distributions along the direction of the jet propagation for different $R F$ power introduced into the discharge (grows from left to right). Experimentally measured voltages at the discharge electrodes and the discharge current density are given in the figure bottom. $L$ is a distance measured from the main discharge dielectric edge

\section{EXPERIMENTAL DATA AND DISCUSSION}

On a basis of the above described procedure, timeaveraged spatial profiles of electron temperature $T_{e}$ and concentration $n_{e}$ along the plasma jet were measured for selected parameters of RF discharge operation in $\alpha$ mode (Fig. 5). The selection was done by means of RF power adjustment so that the lowest value resulted in just a jet downstream reaching the substrate whereas the highest value corresponded to essential spread of the jet along the substrate surface. Intermediate RF power value caused the jet tip touching the substrate. One can see that $\mathrm{T}_{\mathrm{e}}$ is practically unchanged along the plasma jet and has a value of $\approx 1.2 \mathrm{eV}$. It should be noted that experimental data processing was done on a basis of maxwellian EEDF assumption which is justified by used low current RF discharge operation in $\alpha$-mode. Also, spatial profiles of electron concentration variation along a direction of the jet propagation were derived from the photometric data using formula (1). One can see that in case of the lowest selected RF power $n_{e}$ gradually decreases about 8 times at a distance of the jet propagation whereas in case of the highest power the decrease is just about 3. Minor observed jet asymmetry in transverse direction is most likely due to a way of the discharge powering based on different values of RF voltage applied to the discharge electrodes.

\section{CONCLUSIONS}

Upgraded method of non-perturbing photometric study of basic plasma features is applied to planar jet formed by capacitive RF discharge in atmosphere pressure argon. The method is based on photometric imaging of the discharge bremsstrahlung emission in visual spectrum range using inexpensive and simple optical arrangement on a basis of any digital photo camera providing RAW image files. Abilities of the method are demonstrated experimentally by a study of spatial profiles of electron temperature and plasma density in planar jet formed by capacitive RF discharge in atmosphere pressure argon. Results obtained for selected operation parameters of the discharge glowing in $\alpha$-mode have shown that electron temperature is practically unchanged along the jet and has a value of $\approx 1.2 \mathrm{eV}$. Studies of respective time-averaged plasma density profiles have demonstrated gradual decrease of electron concentration along the jet.

Proposed upgraded photometric method can be used as an efficient versatile tool for express remote diagnostics of weakly ionized plasmas of atmospheric pressure discharges with different configurations and working gas media. 


\section{REFERENCES}

1. V.Yu. Bazhenov, R.Yu. Chaplynskyi, R.M. Kravchuk, A.I. Kuzmichev, V.V. Tsiolko, O.V. Yaroshchuk. Atmospheric pressure planar radio frequency discharge with isolated electrodes: glow features and application prospects // IEEE Transactions on Plasma Science. 2017, v. 45, № 12, p. 3218-3223.

2. J.Y. Jeong, S.E. Babayan, V.J. Tu, J. Park, I. Henins, R.F. Hicks, G.S. Selwyn. Etching materials with an atmospheric-pressure plasma jet // Plasma Sources Science and Technology. 1998, v. 7, p. 282-285.

3. J.L. Walsh, M.G. Kong. Contrasting characteristics of linear-field and cross-field atmospheric plasma jets // Applied Physics Letters. 2008, v. 93, issue 11, id. 111501.

4. F. Iza, G.J. Kim, S.M. Lee, J.K. Lee, J.L. Walsh, Y.T. Zhang, M.G. Kong. Microplasmas: Sources, Particle Kinetics, and Biomedical Applications // Plasma Processes and Polymer. 2008, v. 5, № 4, p. 322-344.

5. A. Falahat, A. Ganjovi, M. Taraz, M.N. Rostami Ravari, A. Shahedi. Optical characteristics of a RF DBD plasma jet in various $\mathrm{Ar} / \mathrm{O}_{2}$ mixtures // Pramana. 2018, v. 90, issue 2, article id. 27.

6. X.M. Zhu, Y.K. Pu, N. Balcon, R. Boswell. Measurement of the electron density in atmosphericpressure low-temperature argon discharges by line- ratio method of optical emission spectroscopy // Journal of Physics D: Applied Physics. 2009, v. 42, № 14, p. 142003.

7. D. Mariotti, Y. Shimizu, T. Sasaki, N. Koshizaki. Method to determine argon metastable number density and plasma electron temperature from spectral emission originating from four $4 \mathrm{p}$ argon levels // Applied Physics Letters. 2006, v. 89, issue 20, p. 201502.

8. S. Park, W. Choe, H. Kim, J.Y. Park. Continuum emission-based electron diagnostics for atmospheric pressure plasmas and characteristics of nanosecondpulsed argon plasma jets // Plasma Sources Science and Technology. 2015, v. 24, № 3, p. 034003.

9. V.Yu. Bazhenov, S.M. Gubarev, V.V. Tsiolko, R.Yu. Chaplinskiy. Spatial distribution of continuum radiation from plasma of planar capacitive RF discharge in argon at $1 \mathrm{~atm}$ pressure: photometric study // Problems of Atomic Science and Technology. Series “Plasma Physics". 2016, № 6, p. 199-202.

10. V.Yu. Bazhenov, S.M. Gubarev, V.V. Tsiolko, D.S. Levko. Photometric diagnostics of plasma of planar capacitive RF discharge in argon at $1 \mathrm{~atm}$ pressure // Problems of Atomic Science and Technology. Series "Plasma Physics". 2018, № 6, p. 259-262.

Article received 09.06.2019

\section{ОСНОВНЫЕ ПАРАМЕТРЫ ПЛАЗМЫ ПЛОСКОГО ДЖЕТА ИЗ ЕМКОСТНОГО ВЧ-РАЗРЯДА В АРГОНЕ АТМОСФЕРНОГО ДАВЛЕНИЯ}

\section{В.Ю. Баженов, С.Н. Губарев, В.В. Циолко}

Описан усовершенствованный метод определения основных параметров слабо ионизированной плазмы путем фотометрического исследования континуума тормозного излучения в видимой области спектра. Экспериментально получены усредненные во времени пространственные распределения температуры и плотности электронов в плоском плазменном джете, который формируется с помощью емкостного ВЧ-разряда в аргоне атмосферного давления при горении разряда в слаботочном $\alpha$-режиме.

\section{ОСНОВНІ ПАРАМЕТРИ ПЛАЗМИ ПЛАСКОГО ДЖЕТА 3 СМНІСНОГО ВЧ-РОЗРЯДУ В АРГОНІ АТМОСФЕРНОГО ТИСКУ}

\section{В.Ю. Баженов, С.М. Губарєв, В.В. Ціолко}

Описано вдосконалений метод визначення основних параметрів слабко іонізованої плазми шляхом фотометричного дослідження континууму гальмівного випромінювання у видимій області спектра. Експериментально отримано усереднені за часом просторові розподіли температури і густини електронів у пласкому плазмовому джеті, що формується за допомогою ємнісного ВЧ-розряду у аргоні атмосферного тиску при горінні розряду в слабкострумовому $\alpha$-режимі. 